\title{
Marketing Review Quiz: An Academic Application of the Popular Quiz Game Format
}

\author{
Stacia M. Wert and Gordon T. Gray
}

\begin{abstract}
Adapting the popular quiz game format for use in the classroom can increase student involvement in marketing courses. Game preparation and play are described in detail, and both student and instructor benefits are presented.
\end{abstract}

Computer simulation games are becoming an increasingly popular teaching tool on college campuses, and many business courses use these games to stimulate student interest and learning. Markstrat (Larreche and Gatignon 1977), for example, is a well-accepted simulation game frequently included in advanced marketing courses. Lengthy preparation and play time, however, limit the use of simulation games in marketing courses requiring coverage of an extensive amount of material, such as the basic marketing course. This is unfortunate since other factors, such as large class sizes and diverse student backgrounds, often present barriers to student learning and satisfaction in the basic course (Miller 1987).

A simpler tool is needed to encourage student involvement in the basic marketing course. As Anderson (1987) has pointed out, this course may be the most important in the marketing curriculum, since it provides a foundation for both subsequent marketing courses and students' professional development. Adapting the popular quiz game format to an academic setting provides one means of stimulating student interest in this important course.

\section{BACKGROUND}

Most professors and instructors vividly remember their first semester of teaching as a challenging and simultaneously trying

Stacia M. Wert and Gordon T. Gray are in the Division of Marketing at the University of Oklahoma, Norman, Oklahoma. experience. This initial experience often occurs while the individual is a graduate assistant who must juggle the many responsibilities associated with graduate school in addition to his or her teaching assignment, and gauging student understanding of course material prior to examinations is made difficult by inexperience. Inability to assess students' comprehension may result in examinations that are too difficult, thereby contributing to student disinterest and dissatisfaction. This undesirable scenario stimulated the authors to develop a simple but effective teaching technique using the quiz game format popularized by numerous television game shows and board games.

Television shows, board games, and parlor games structured in the familiar quiz format (question-answer) are generally equated to trivia. With slight modifications, however, these games become more educational than trivial. The quiz game format is easily adapted to basic marketing courses and offers educational benefits to students while providing instructors with valuable feedback.

\section{PLAYING THE GAME}

Marketing Review Quiz (MRQ) was developed as a study and review session to be played in the class period prior to a class in which a quiz or examination is administered. Playing the game several days before a scheduled examination allows the instructor ample opportunity to clarify any student misunderstanding or confusion regarding course material.

Instructor preparation involves defining 
four to eight categories that are broad enough to encompass five or more objective questions, and the time required for preparation is minimal: the task can generally be completed in less than an hour. Most questions should address subject material covered in lecture and reading assignments, butincluding a "fun" category (sports, movies, popular music, local campus news, etc.) generates initial student interest that carries forward into the remaining marketing categories. Table 1 illustrates actual categories and questions used in a basic marketing course.

TABLE 1

MARKETING REVIEW QUIZ QUESTION LIST

\begin{tabular}{|c|c|c|}
\hline Category & Points & Question (Answer) \\
\hline \multirow[t]{5}{*}{$\begin{array}{l}\text { Buyer } \\
\text { Behavior }\end{array}$} & 400 & $\begin{array}{l}\text { What is a stimulated need requiring satisfaction? } \\
\text { (a motivation) }\end{array}$ \\
\hline & 400 & $\begin{array}{l}\text { What are two methods that consumers use to avoid information overload? } \\
\text { (selective: retention, exposure, action, and/or distortion) }\end{array}$ \\
\hline & 400 & $\begin{array}{l}\text { What social class term applies to the lower middle class plus the upper lower class? } \\
\text { (the mass market) }\end{array}$ \\
\hline & 400 & $\begin{array}{l}\text { Pavlov's dog experiment is an example of what type of learning theory? (stimulus- } \\
\text { response) }\end{array}$ \\
\hline & 400 & $\begin{array}{l}\text { What are the id, ego, and superego? } \\
\text { (Freud's } 3 \text { elements of the mind) }\end{array}$ \\
\hline \multirow[t]{5}{*}{$\begin{array}{l}\text { Market } \\
\text { Research }\end{array}$} & 300 & $\begin{array}{l}\text { What is the single best source of secondary marketing research information? (the } \\
\text { U.S. government) }\end{array}$ \\
\hline & 300 & What is the major criticism of mail surveys? (high nonresponse rates) \\
\hline & 300 & $\begin{array}{l}\text { What are two significant disadvantages associated with personal interview survey } \\
\text { methods? (potential for interviewer bias, high expense, and/or time consuming) }\end{array}$ \\
\hline & 300 & $\begin{array}{l}\text { What is the popular sampling method that allows statistical inferences to be drawn to } \\
\text { the general population? (random sample) }\end{array}$ \\
\hline & 300 & $\begin{array}{l}\text { What name is applied to an ongoing process to generate, process, store, and } \\
\text { retrieve information to aid decision making? (marketing information system) }\end{array}$ \\
\hline \multirow[t]{5}{*}{$\begin{array}{l}\text { More } \\
\text { Marketing }\end{array}$} & 200 & $\begin{array}{l}\text { What term is associated with placing emphasis on a customer orientation and } \\
\text { profitable sales? (the marketing concept) }\end{array}$ \\
\hline & 200 & $\begin{array}{l}\text { What are three ways to satisfy a want or need? (produce, steal, or exchange for a } \\
\text { product/service) }\end{array}$ \\
\hline & 200 & $\begin{array}{l}\text { What are the requirements for exchange? (two or more parties, voluntary } \\
\text { participation, products of value, and communication) }\end{array}$ \\
\hline & 200 & $\begin{array}{l}\text { Name two of the four competitive market structures. (pure markets, monopolistic } \\
\text { competition, oligopoly, and/or monopoly) }\end{array}$ \\
\hline & 200 & $\begin{array}{l}\text { What are two of Porter's three generic strategies? (cost leadership, differentiation, } \\
\text { and/or focus) }\end{array}$ \\
\hline Just & 100 & What is the name of the popular Jim Davis comic? (Garfield) \\
\hline \multirow[t]{4}{*}{ for Fun } & 100 & How many seams are on a football? (four) \\
\hline & 100 & What movie won best picture for 1989 ? (Rain Man) \\
\hline & 100 & Who won the 1989 Super Bowl? (San Francisco) \\
\hline & 100 & $\begin{array}{l}\text { What two American battleships sank at Pearl Harbor and were never refloated? (the } \\
\text { Arizona and the Oklahoma) }\end{array}$ \\
\hline
\end{tabular}


Administering MRQ is a simple procedure that requires approximately 45 minutes. The game has been played with class sizes ranging from 30 to 60 students. One instructor can comfortably handle up to 10 teams of five to eight students each, and with an assistant to help referee the game, even more teams are possible.

While students form teams, the instructor displays the game board on an overhead projector or chalk board. (Table 2 illustrates an actual game board.) The game board must be easily accessible, enabling the instructor to designate which questions have been answered. Drawing a large $X$ through the point total as the question is requested is sufficient. A scoreboard listing each team's point total is the final game requirement.

TABLE 2

MARKETING REVIEW QUIZ GAME BOARD

\begin{tabular}{cccc}
\hline \hline $\begin{array}{c}\text { Buyer } \\
\text { Behavior }\end{array}$ & $\begin{array}{c}\text { Marketing } \\
\text { Research }\end{array}$ & $\begin{array}{c}\text { More } \\
\text { Marketing }\end{array}$ & Just for Fun \\
\hline 400 points & 300 points & 200 points & 100 points \\
400 points & 300 points & 200 points & 100 points \\
400 points & 300 points & 200 points & 100 points \\
400 points & 300 points & 200 points & 100 points \\
400 points & 300 points & 200 points & 100 points \\
\hline
\end{tabular}

Game play is simple and proceeds quickly because of students' familiarity with quiz games and trivia contests. The instructor begins play by randomly selecting a category; after the first question, categories are selected by the last correctly responding team. The instructor reads the questions, judges the responses for accuracy, and tallies the score. The first team member to raise his or her hand may respond when recognized. Incorrect responses lose that question's point total and a team may only answer a question once. Play continues until all questions have been addressed or class time expires.

During play, students should be allowed to access their notes, to permit them to update or clarify their understanding of topics as the game progresses. Class discussion should not be limited to specific categories and questions, since a game question often stimulates student queries regarding a related concept. It is not important to address all of the questions on the game board; rather, the idea is to identify and clarify concepts confusing to the students.

The winner of the game is the team accumulating the most points during a class session. Winning team members receive a token prize (miniature candy bars, college pencils or pens, etc.) to help stimulate competitiveness and encourage game preparation, and in addition the instructor may allow the winning team to select the initial category when MRQ is next played.

\section{BENEFITS}

MRQ offers many benefits for both students and instructor. Students become highly involved with the game and adopt varying strategies to enhance their team's performance. For example, some teams assign each team member primary responsibility for one game board topic, and during the game that student keeps turned to the appropriate section of notes or textbook readings. Games become highly competitive, with scores carefully monitored by team members. Team membership generally remains constant throughout the semester and often produces outside class study groups.

Many students prepare for the MRQ session as though it were an actual examination, and use the session to reinforce and clarify their understanding of class topics. Other students use the session as a refresher prior to studying formally for examinations. In either 
instance, the review sessions enhancelearning.

If an instructor is unable to use the game during class time, students can be given questions and asked to derive answers as an outside classroom learning aid. This technique, closely resembling use of a study guide or practice examination, could increase student interest in outside classroom study activities. However, many benefits of MRQ are realized through the student's involvement and the enthusiastic response generated by a competitive setting.

Students often mention that the game helped them develop an overall understanding of marketing topics. These opinions have been expressed both formally, through end-ofsemester course and instructor evaluations, and informally, through conversations with the instructors. Many students are amazed that studying for examinations can be fun.

MRQ is a useful gauge of how well students are comprehending course topics. If students handle the review questions easily, they may be prepared for a challenging examination. The review session may also indicate that students are failing to grasp important concepts. In either instance, the sessions provide instructors with a great source of useful feedback.

\section{CONCLUSION}

Many college students enjoy watching television quiz shows and playing trivia quizzes or other games that require varying degrees of thought. MRQ allows a marketing instructor to capitalize on this gaming interest easily. The game is well suited to large classes consisting of students with diverse educational backgrounds and goals, and it adds fun and excitement to the learning process, thus enhancing both student interest in marketing concepts and understanding of those concepts. Both marketing majors and nonmajors find that the experience helps establish a firm foundation for further marketing and business coursework.

\section{REFERENCES}

Anderson, Elizabeth Scott (1987). "The Psychological Contract: A Method for Increasing Student Satisfaction.” Journal of Marketing Education, 9 (Summer): 25-29.

Larreche, J., and H. Gatignon (1977). Markstrat: A Marketing Strategy Game. Palo Alto, CA: The Scientific Press.

Miller, Fred (1987). "Test Frequency, Student Performance, and Teacher Evaluation in the Basic Marketing Class." Journal of Marketing Education, 9 (Summer): 14-19. 